\title{
Nonprofit Policy Forum
}

Volume 2, Issue 1

2011

Article 3

\section{A New Era of Collaborative Government- Nonprofit Relations in the U.S.?}

John Casey, Baruch College, City University of New York

\section{Recommended Citation:}

Casey, John (2011) "A New Era of Collaborative Government-Nonprofit Relations in the U.S.?," Nonprofit Policy Forum: Vol. 2: Iss. 1, Article 3.

DOI: $10.2202 / 2154-3348.1010$ 


\title{
A New Era of Collaborative Government- Nonprofit Relations in the U.S.?
}

\author{
John Casey
}

\begin{abstract}
The growth of the nonprofit sector in the last decades and its greater salience in the delivery of public goods and services has been accompanied by the development of new institutions and processes for managing the relations between nonprofits and governments. This article documents a number of recent initiatives to strengthen government-nonprofit relations in the U.S. and analyzes the policy agendas that are driving them.
\end{abstract}

KEYWORDS: government-nonprofit relations, partnerships, compacts, collaborations

Author Notes: Earlier versions of sections of this article have appeared in Casey et al. 2010, Casey 2009, and Casey et al. 2009. The author would like to thank the three anonymous Nonprofit Policy Forum reviewers for their helpful comments. 
Casey: Collaborative Government-Nonprofit Relations in the U.S.

\section{Introduction}

In June 2010 the Nonprofit Sector and Community Solutions Act (H.R. 5533) was introduced into the $111^{\text {th }}$ Congress. According to its principal sponsor, Representative Betty McCollum (D-MN), the aim was "to improve the relationship between the federal government and nonprofits ... by making the federal government a more productive partner with nonprofit organizations" (McCollum 2010). Among other measures, the Act sought to establish a crosssector Council on Nonprofit Organizations and Community Solutions that would bring together representatives from government, nonprofits and business, and a federal government Interagency Working Group on Nonprofit Organizations that would evaluate recommendations from the new Council and coordinate policymaking relating to nonprofits. The proposed bill was the latest salvo in a long history of efforts to recalibrate the relationship between the government and nonprofit sectors. The growing salience of nonprofits in the last decades has outstripped the capacity of existing structures to manage the interactions between the sectors, and the relations between governments and nonprofits in the U.S., have been characterized as being poor, ambiguous, and in need of new paradigms of interaction (Aspen Institute 2000, Grønbjerg and Salamon 2004, Young 2006).

In industrialized countries around the world there has been a trend towards more collaborative forms of government-nonprofit relations and an institutionalization of the conduits of interactions between the sectors (Salamon 2006) and the U.S. appears to be following suit. Symptomatic of this shift in the social contract between governments and nonprofits is the emergence of new structures and processes that seek to overcome the tensions between the sectors and give explicit recognition to the unique role of the nonprofits in service delivery and policy consultation. New "deliberate relations" (Carter and Speevak Sladowski 2008) are increasingly a defining feature of government-nonprofit relations in other countries and there is ample evidence of their development in the U.S. In addition to the proposed federal act there are other national initiatives as well as numerous state- and city-level initiatives.

This article analyzes emerging initiatives in strengthening governmentnonprofit relations in the U.S., in the context of the broader international evolution of deliberate relations, and speculates on whether they are ushering in a new era of closer collaborative relations. 


\section{The Increasingly Deliberate Relations between the Sectors}

Governments and nonprofits are inextricably linked in a complex series of interactions that configure their joint and separate interests. Nonprofits are independent organizations, but they almost invariably seek some "good" for their constituencies, members and clients, which involves extensive transactions with government; while governments are increasingly dependent on nonprofits for service delivery, policy input, and the promotion of civic action. Voluntarism, associationalism, communitarianism, and other manifestations of private voluntary activity are all historical icons of the U.S. political, economic and social systems (Anheier 2005, Salamon 2006) but the reality is that government, through its control of institutional legitimacy and its capacity to directly fund activities or to confer fiscal advantages, is a crucial enabler of nonprofit endeavors. The relationship between the sectors can be described as a mixture of resource interdependency, principal-agent hierarchies, and mutual accountability (Saidel 1991, Brown and Jagadananda 2007).

The most commonly referenced typologies that seek to describe and analyze these interdependent relationships focus on their modes or attributes. Najam (2000) terms the relationship cooperation when government and nonprofits have similar ends and similar means, confrontation in the case of dissimilar ends and dissimilar means, complementarity in the case of similar ends but dissimilar means, and co-optation in the case of dissimilar ends but similar means. In a similar vein, Young (2006) identifies supplementary, complementary, and adversarial as the three dominant modes of relationships between the sectors. The modes are not mutually exclusive, and the political economy of the operational environment determines how they mix and match in the continuing dynamics between the sectors, which can be characterized as primarily vertical and hierarchical or as horizontal and collaborative. Saidel (2011) maps these dynamics along a continuum between governance by proxy, in which principalagent dynamics dominate, and governance by partnership.

The analysis in this article is firmly rooted in an institutional perspective (Smith and Grønbjerg 2004) which focuses on the structures and processes that continue to shape these dynamics. These structures and processes are "path dependent" in that they are the legacy of the economic, social and political history of their polity, but that resulting institutions are also now actors in their own right, pursuing their interests and so determining the future direction of the relations. In the three decades since the beginning of the "global associational revolution", the market and civic imperatives that characterized the early expansion of the nonprofit sector have been largely institutionalized through contracting and policy consultation regimes (Salamon 2006, Saidel 2011). This paper focuses on 
Casey: Collaborative Government-Nonprofit Relations in the U.S.

significant markers of this institutionalization and on the bureaucratic logics that drive the resulting institutional arrangements between the sectors.

The policy agendas that have shaped the increasing salience of nonprofits are shifting and often contradictory -- collaborative symbiosis coexists with headbutting antagonism -- but in recent years dominant themes seem to be emerging. Advocates for the nonprofit sector are generally seeking explicit recognition of the key and increasing role it plays in delivering services and promoting civil action; they seek greater stability and coherence in the currently uncoordinated and inefficient flows of funding from governments; and they seek some delineation of the independence of the sector and protection for the right to advocate on behalf of constituencies. Legislators and bureaucrats are generally seeking to strengthen the nonprofit sector, but are also seeking to foster more "discipline" in terms of performance and transparency in the services delivered by nonprofits and in the input they provide into the policy process. There are multiple uncertainties in the relationships between the sectors (Saidel 2011), and all parties have an interest in promoting processes that might reduce them.

As transactions between the sectors have increased, the relationships have become increasingly deliberate at a sector-to-sector level, and there has been a notable expansion of the institutional structures and processes that are being created to manage them. These new deliberate relations go beyond specific contract or advisory relations that focus on a single agency, program or project; instead, they seek to foster stronger government-nonprofit relations across a range of service delivery and policy making functions and to bring some order to the somewhat chaotic nature of the former haphazard growth. They include the establishment of new government lead agencies or executive appointments that focus on nonprofit relations, as well as new nonprofit coordinating bodies and trade associations that seek to mediate relations with government. Even where formal entities are not being created, the two sectors may use existing structures to create new processes that foster much broader and deeper deliberate relations.

This dynamic has been common to all industrialized democracies. A recent Canadian document illustrates the extent of these deliberate relations (CVSRD 2009:1):

"Interest in strengthening relationships between governments and the non-profit voluntary sector has resurfaced in several Canadian provinces and territories over the past few years. Leadership organizations; chambers, networks, and councils, in the nonprofit/voluntary sector have been gaining momentum as they build connections, cohesion, and capacity within the sector. Government departments, units, and branches, have broadened their scope from volunteer recognition to recognizing the contributions that 
voluntary organizations make to society. With each sector coming to the table possessing renewed energy and a clearer focus, there is even greater will to work collaboratively and to leverage their collective capacity to build resilient communities."

In some countries, the efforts to strengthen deliberate relations have resulted in the signing of sector-level framework agreements that commit the parties to joint operating principles and specific actions to increase collaborations. The first such agreement, The Compact on Relations between Government and the Voluntary and Community Sector in England, was signed in 1998 and was seen as representing an unparalleled repositioning of the nonprofit sector (Kendall 2003). The term compact has since become the most commonly used generic descriptor for such agreements, but other terms such as accord, charter, concordat, cooperation program, protocol, partnership and strategy are also used in different countries (Casey et al. 2009).

Despite very different histories of nonprofit development, countries as diverse as Australia, Canada, Estonia, France, and Spain, as well as supranational entities, have developed some form of compacts over the last decade, either as bilateral agreements or as unilateral government policy developed with broad consent from the nonprofit sectors (Osborne and McLaughlin 2002, Kendall 2003, Bullain and Toftisova 2005, Casey et al. 2010). Other countries such as New Zealand and Hungary, while not signing formal compacts or promulgating specific policies, have strengthened deliberate relations through the establishment of new flagship government and nonprofit coordinating structures. There are considerable variations between countries in the characteristics and outcomes of these initiatives but the similarities in processes appear to be greater than the differences in outcomes. Compacts and other deliberate relations have helped nonprofits gain a stronger footing in their horizontal relations with government (Kendall 2003) and have allowed governments to require more accountable policy input and service delivery from nonprofits.

The first paragraphs from the foreword of the English Compact illustrate the principles and objectives embodied in these agreements (Commission on the Compact 2007: Foreword):

"The voluntary and community sector has a vital role in society as the nation's 'third sector', working alongside the state and the market. Through its engagement of volunteers, the services it provides, and the support it gives to individuals and groups, its contribution to community and civil life is immense, invaluable and irreplaceable.

This Compact is aimed at creating a new approach to 
Casey: Collaborative Government-Nonprofit Relations in the U.S.

partnership between Government and the voluntary and community sector. It provides a framework to enable relations to be carried out differently and better than before. "

Compacts are high-level, formal enabling instruments that define the institutional relationship between government and nonprofits, but they are only the "tip of the iceberg" of the much wider base of multiple formal and informal processes that have emerged in the context of the tendency to strengthen deliberate relations. As Kendall (2003) and Fyfe (2005) note, the creation of compacts in England and other jurisdictions in the U.K. was integral to the Blair Labour government's Third Way political philosophy, which sought to combine neoliberalism with a communitarian agenda that elevated nonprofits to a more central role in service delivery and policymaking. But over the last decades, such rapprochement between nonprofits and governments and the mainstreaming of nonprofits as service providers and participants in policy negotiations has not been unique to the U.K., nor restricted to fellow travelers of Third Way philosophies. New collaborative partnerships between governments and nonprofits are embedded in the various national variants of New Public Management and governance approaches to the management of public goods and services (Osborne and McLaughlin 2002, Kendall 2003, Casey and Dalton 2006). These approaches can reflect either, or both, "conservative" top-down marketization or "progressive" bottom-up partnerships (Lewis 2005), and whichever side of the ideological fence governments fall, they have all tended to promote an expanded role for nonprofits. With the post-2008 global economic crisis, there has been some peeling back of funding and fiscal privileges for nonprofits, and increasing pressure on nonprofits to demonstrate impacts, but nonprofits continue to play a central role in the different interpretations of governance and in future strategies for the delivery of public goods and services.

The emergence of new structures and processes that foster deliberate collaborative relations in different countries has been the result of both independent development processes and policy convergence. Despite the persistence of historical "national scripts" (Anheier and Kendall 2001) that continue to independently configure the nonprofit sector and its relationships to governments in different countries, there appears to be a common global discourse that speaks about the rise of a larger and more salient nonprofit sector, the increasing reliance of governments on contracting with nonprofits for the delivery of public goods and services, the development of new forms of policy dialogues that seek to more effectively channel input by nonprofits, and the search for new forms of coordination and liaison. The origins of many such processes can be traced back to the early 1990s, based on a common theme of the need to address tensions arising from the contracting models of the 1980s and 1990s and the need 
to create a new culture of collaboration and effectiveness that can better harness the expanding roles of nonprofits. The emerging collaborative relations between governments and nonprofits also reflect a broader trend towards strategic alliances and coalitions that is evident within the nonprofit sector itself and in nonprofitbusiness relations (Yankey and Willen 2010). At the same time, there has been significant policy transfer and convergence, with many post-1998 processes to create formal agreements making some reference to the English Compact, which continues to be the benchmark by which other jurisdictions measure their own processes.

Nonprofits now occupy a larger political, economic and social space in all democratic societies and previous institutional mechanisms for regulation of nonprofits and their relationship to other social agents, such as tax codes, registry of organizations, granting of charity status, "subsidiarity" or "pillarization", are considered insufficient to promote, foster, protect, and oversee the new service delivery and policymaking relations. Despite the significantly different social origins of government-nonprofit relations in different countries, there is a global trend to new paradigms of collaboration and institutionalization (Salamon 2006). Compacts and other processes of deliberate relations are an attempt to go beyond previous purchaser-provider vendor relationships between government and nonprofits and move to a more mutual obligation approach that replaces a "contract culture" of vertical relations with a "partnership culture" of more horizontal relations (Kendall 2003).

Deliberate relations have become core strategies for coordination and liaison, but their implications for government-nonprofit relations continue to be debated. The new structures and process are seen as both heralding a new era in the evolving relationship between governments and nonprofits, but also as necessary peace treaties between sectors that have been at odds due to previous excesses of the contracting and competitive tendering approaches or because of a history of mutual distrust and political rivalry, as well as much needed coordination mechanisms for interactions beset by fragmentation and inefficiencies. Some argue that they are symptomatic of emerging relational and network governance regimes, and that it is "the best of times" for nonprofits as they have never been so central to service delivery and policy making. However, others argue that the new deliberate relations represent the "the worst of times" because the new relations have led to a loss of nonprofit autonomy, a concentration of power in government hands, and the instrumentalization of the nonprofit sector (Craig, Taylor and Parkes 2004, Casey and Dalton 2006). In the U.S., many nonprofits are celebrating the new possibilities for collaboration offered by the Obama administration and by initiatives such as the Nonprofit Sector and Community Solutions Act, but there continues to be a strong undercurrent that remains profoundly skeptical of proximity to government. Some 
Casey: Collaborative Government-Nonprofit Relations in the U.S.

commentators scorn the "fawning" between the sectors and question whether the relationship between the Obama administration and foundations is becoming "too close for comfort" (Paletta 2010, Hudson Institute 2010).

\section{Deliberate Relations in the U.S.}

In the U.S. there are contracts and other agreements between governments and specific organizations, or between governments and small groups of organizations, to pursue specific goals such as the provision of adult literacy education or the regeneration of a neighborhood. But there are no broader, sectorto-sector agreements that would be the direct equivalents of the compacts that have emerged in numerous other countries, ${ }^{1}$ and few of the other structures and processes of deliberate relations (Casey 2009). Government matters less to the collective organizational psyche of U.S. nonprofits than to nonprofits in other, more State-centric, polities and less energy has been spent in the last decades in the "feed and care" of the relationship between government and nonprofits. This has been particularly true in the economic boom times when the focus was primarily on increasing philanthropic donations, developing business venturing and stimulating social entrepreneurship.

The following intersecting dynamics appear to have militated against the development of closer institutional ties between government and nonprofits in the U.S.:

- The dominant political and cultural norms continue to be the independence of private endeavors and "small government". The nonprofit sector is regarded as a paragon of private and voluntary initiatives, and there is a strong vein of distrust about attempts to strengthen ties to government.

- A long history of privatization and marketization of service delivery has meant that nonprofit organizations are more accustomed to functioning under marketplace rules and competing with private for-profit providers, and they have not necessarily sought to demarcate a privileged relationship for nonprofits.

- Federal structures, and the resulting multi-layered national, state and local funding streams and oversight responsibility makes it hard to determine which levels of government should be party to the development of sectorlevel agreements, and the size, diversity, and complexity of the nonprofit sector make it difficult to identify interlocutors that represent nonprofits.

\footnotetext{
${ }^{1}$ The word compact is widely used in the U.S., but most often refers to agreements either between two or more universities or between universities and local stakeholders, which seek to promote closer links between universities and the communities that surround them. "Campus compacts" are often touted as evidence of universities meeting their social responsibilities.
} 
- Private philanthropy plays a more prominent role in funding nonprofits than in most other countries, so much of the focus and energy of nonprofits is spent on cultivating relationships with corporations, foundations and individual donors.

- The structure of philanthropy has created intermediary organizations, such as community foundations and the United Way, which function as both donor organizations (they collect donations from the public and corporations and give grants to nonprofits) and peak coordinating organizations (they represent the interests and promote the work of nonprofits). The dual role of such organizations further complicates the demarcation of the possible roles of the various stakeholders in sectorbased agreements.

While these factors may explain why there have not been sector-wide agreements, they should not be interpreted as evidence that U.S. exceptionalism has provided alternative pathways to resolve the concerns that have emerged in other countries. On the contrary, the Aspen Institute (2000:4) noted that "the relationship between government and the nonprofit sector has grown without a great deal of attention or focus" and that ambiguity exists about how their relationship should best evolve. Grønbjerg and Salamon (2004) decried the poor state of relations between the sectors and recommended a new paradigm of government-nonprofit interaction in which nonprofits acknowledge the legitimate performance requirements of government, and government acknowledges the advocacy responsibilities of nonprofits and its own obligation to provide greater stability in public funding for nonprofits. Representative McCollum in various speeches in support of her proposed legislation has claimed that despite the tremendous significance of the nonprofit sector, the federal government largely ignores it and nonprofits lack institutional presence within the federal administration (McCollum 2010).

The response to these concerns is a rewriting of the social contract between the sectors (Young 2006) at national, state and local levels. At the national level, the need for better relations tends to be couched in terms of policy input, while at state and local levels, where there is a more coalface relationship, the push for better relations are framed more as the need to ensure more effective and efficient government contracting processes and nonprofit compliance with performance criteria. The mutual dependence between the sectors has resulted in dynamics that increasingly favor more horizontal, collaborative relations, but hierarchical structures continue to be central, particularly in times of budget shortfalls when public managers have less discretion to negotiate policy and programmatic decisions (Saidel 2011). 
Casey: Collaborative Government-Nonprofit Relations in the U.S.

\section{$\underline{\text { National Initiatives }}$}

There have been numerous efforts by advocates for closer ties between the sectors to create more deliberate relations at a national level. In the 1970s, the Filer Commission recommended that Congress create a permanent commission on nonprofits, with the following mission (Filer 1975: 192):

"To study in depth the existing relationships between government and the nonprofit sector; to seek ways of encouraging and improving existing relationships in a spirit of cooperation while preserving the effectiveness and independence of the sector and the private initiative which gives it life; and to serve actively in close consultation with government as an ombudsman in the protection of the interests of the private nonprofit sector."

While the hopes of the advocates for this new commission were thwarted in the transition to the Carter administration and it never materialized, the work of the Filer Commission led to the creation in 1980 of the first sector-wide nonprofit industry association, the Independent Sector (Hall 2006), and the push for new coordination structures has never left the policy agenda. The Filer recommendation for a permanent commission has resurfaced periodically, often in the form of calls to create a federal agency for nonprofits that would match the work done by the Small Business Administration created in 1953 to "aid, counsel, assist and protect the interests of small business concerns" (see Rucker 2008, Sherlock and Gravelle 2009, McCollum 2010).

On the campaign trail, then Senator Barack Obama proposed creating a Social Entrepreneurship Agency, which he envisaged as residing in the Corporation for National and Community Service (Perry 2008), and after his victory, he created a new White House Office on Social Innovation and Civic Participation to identify and scale up successful nonprofit initiatives by developing partnerships between the government and nonprofits, businesses, and philanthropists, and by promoting greater civic participation and national service. Meanwhile, in November 2009, the Congressional Research Service issued a report, An Overview of the Nonprofit and Charitable Sector, which canvassed the need to increase funding to nonprofits and again broached the possibility of creating a federal oversight agency along similar lines to the Small Business Administration (Sherlock and Gravelle 2009), and the proposed Nonprofit Sector and Community Solutions Act calls for a new cross-sector Council and federal cross-agency Working Group. 
For the nonprofit sector, a key component in advocating on behalf of the sector and for better relationships with government has been the development of state-level associations, modeled in large part on the for-profit chambers of commerce. While the first such association was created in New York in 1927, the majority have been established in the last two decades and they are now present in 35 states. The first national meeting of such associations in 1989 (only 12 existed then) resulted in the creation of the National Council of Nonprofit Associations (now the National Council of Nonprofits) which in its first major public policy statement in 1992 requested a White House conference to "forge a stronger partnership between nonprofits and government," as well as for a complete reexamination of government funding and contracting practices, for tax policies to encourage private giving, and for the protection of nonprofits' right to lobby (National Council of Nonprofits 2010).

In recent years there have been various national initiatives to develop a stronger voice for nonprofits and sector-wide principles for collaborating with government, including the Aspen Institute's The Nonprofit Sector and Government: Clarifying the Relationship (Aspen Institute 2002) the Voice, Value and Votes-V3 campaign (V3 2008), and the Declaration for America's Nonprofit and the Nonprofit Constitution sponsored by the National Council of Nonprofits (Nonprofit Congress 2008). In March 2009, a "call to action" signed by more than 400 nonprofit CEOs and academics was published as the Forward Together Declaration (JHUCCS 2009). The Forward Together Declaration states that it is time to "renew the compact" with the nonprofit sector (note that compact is used here in the conceptual sense and does not refer to a specific past document), and calls for the establishment of a Commission on Cross-Sector Partnerships and the development of a set of Partnership Principles. The text of the Forward Together Declaration invokes many of the same discourses that have fostered the establishment of new structures of deliberate relations in other countries. It states (JHUCCS 2009: 2):

"America's nonprofit organizations have been left to fend for themselves in the face of a variety of recent challenges: lack of public understanding, declining government support, inadequate growth of private giving, unequal access to investment capital, difficulties recruiting and retaining talented staff, and an imperfect capital market for scaling up promising innovations. To remedy these and related problems and allow our citizen sector to make the contributions to our national well-being of which it is capable, America needs to renew its compact with the citizen sector. This will involve a variety of steps." 
Casey: Collaborative Government-Nonprofit Relations in the U.S.

The first step it recommends is to "improve government-nonprofit partnerships - at all levels", and calls for "a permanent institutional presence for the nonprofit sector at all governmental levels" (JHUCCS 2009: 3).

\section{$\underline{\text { State and Local Initiatives }}$}

The federal architecture of the U.S. polity makes national solutions difficult, if not impossible, because so much of the negotiation over policy and the majority of contracting processes take place at subnational levels. At state and local levels there have been similar trends towards more horizontal governance, as evidenced by recent initiatives by both governments and the nonprofit sector to create new liaison structures and processes. In 2003, Governor Granholm of Michigan established the Michigan Office of Foundation Liaison to broker strategic partnerships between the state and foundations, and in 2008 Governor Schwarzenegger of California appointed a Secretary for Service and Volunteering to improve coordination of volunteer efforts between the state's agencies (both states claim in various press releases and descriptions of the offices that theirs was the first cabinet-level position for nonprofits in the nation). There is no accurate documentation of the number of such positions that have been created throughout the U.S. but they continue to appear, with the most recent being the January 2011 appointment of a Connecticut legislator Deborah Heinrich to the new cabinet position of Nonprofit Liaison to Governor Malloy and head of a new Community Nonprofit Human Services Cabinet.

From the nonprofit sector, a number of state associations are creating new processes to unite the sector and strengthen its capacity to negotiate with government. These include The California Association of Nonprofits, which is promoting Ensuring Nonprofit Integrity, an assessment tool for accountability that seeks to "reframe the public discussion about nonprofit practice and the role nonprofits play in society" (California Association of Nonprofits 2007), and The Alliance of Arizona Nonprofits, which published One Voice Arizona: A Nonprofit Agenda that promotes a common vision of the nonprofit sector based on strategies such as "speak with one voice", "increase public awareness" and "promote accountability" (Arizona Nonprofit Alliance 2008). Also, similarly to the national Forward Together Declaration, there have been calls to establish new relationships at state level, including recommendations that there be a state-bystate adoption of new "state-nonprofit partnership compacts" (Auger 2011).

One of the most comprehensive examples of the development of new structures and process of deliberate relations at subnational level has been in New York City, where a series of coordinated initiatives is being launched that are fundamentally restructuring the relationship between the city administration and nonprofits. There are 42,000 registered nonprofits in New York City, 2,500 of 
which contract with city government for the delivery of services. The New York City administration, led by Mayor Michael Bloomberg, has recently instituted a number of programs to strengthen its relations with nonprofits, particularly those with city contracts. These programs, collectively referred to as the Mayor's Nonprofit Initiative, include:

- An online portal for assisting nonprofits.

- A Chief Services Officer to promote service to the community (like Michigan and California, press releases from the Mayor's Office claim that the appointment is the first in the country!).

- A Nonprofit Contract Facilitator in the Mayor's Office of Contracts Services.

- A Memorandum of Understanding with the nonprofit Human Services Council that guarantees Cost of Living Adjustments in city contracts.

- A Standard Contract to be used by all city agencies.

- The Health and Human Services Accelerator, a new unit that will focus on increasing efficiency and transparency in the relationship between government and the 1,300 nonprofit providers that have contracts with 12 city human services agencies, but will also gather data on the nonprofit sector in the city and provide capacity building programs to nonprofits.

- The Mayor's Office of Contract Services and the Fund for the City of New York offer bridge loans through the Returnable Grant Fund, so the City is not only the contractor but also in effect the guarantor during cash flow difficulties. Other city-sponsored fiscal programs to assist nonprofits in weathering the fiscal crisis are offered through lines of credit and group purchasing.

These initiatives are coordinated through a series of working groups convened by the Office of the Deputy Mayor for Health and Human Services that include city agency and nonprofit representatives as well as academics, consultants and representatives from private philanthropy. The initiatives have been introduced with relatively little fanfare and there have been no overarching formal agreements; yet the density of the new deliberate relations created by these initiatives will in effect function as a "de facto" compact between the city administration and nonprofits and herald a new era of cooperation. The primary focus of the Mayor's Nonprofit Initiative is on the subset of nonprofits that have contracts with the city, but at the same time it aspires to facilitate relations also with the wider nonprofit sector. 
Casey: Collaborative Government-Nonprofit Relations in the U.S.

It should be noted that in New York City the relationship between city government and nonprofits is also marked by the reality that the Mayor himself is the city's richest man and largest philanthropist, giving over $\$ 40$ million annually in grants through the Bloomberg Family Foundation and many millions more through other charities and foundations. The complex nature of the interplay between the Mayor's roles as the City's chief executive and its chief philanthropist became even more evident in March 2010 when he appointed Patricia Harris, the First Deputy Mayor in the city administration, as the chief executive and chairwoman of the Bloomberg Family Foundation, positions she would hold in conjunction with her city responsibilities.

\section{The Evolving Policy Agendas}

While the genesis of the majority of the U.S. initiatives outlined in this article is in dynamics that began before the current financial crisis, the upheavals since 2008 appear to have heightened the sense that nonprofits should be paying more attention to their relationship with government. During the economic bubble, nonprofits focused their energy on private philanthropy and entrepreneurial initiatives, but now more attention is being given to what government can provide and to government policies that impact constituencies. In response to the American Recovery and Reinvestment Act of 2009, The National Council of Nonprofits urged nonprofits to again assert their "historic role as champions of the common good" by helping monitor government operations and ensuring accountability (National Council of Nonprofits 2009). This shift in attitude in response to the financial crisis has served to reinforce earlier initiatives in favor of more collaborative relations with government, and they are significantly altering policy agendas. There continue to be contradictory dynamics -- budgetary crises at federal, state and local levels have seen many administrations retreat into more control and command modes, and there is pushback from those concerned about developing too close a relationship with government -- but the momentum appears to continue to push to more interdependency between the sectors.

Government regulation and other oversight of the operations of nonprofits is increasingly accepted by the nonprofit sector as the price to be paid for funding opportunities and fiscal advantages, as well as a response to possible security concerns generated by post 9-11 scrutiny. The recent changes in IRS reporting requirements, which have extended at least minimal Form 990 reporting to all nonprofits, is expected to considerably reduce the number of registered organizations as inactive ones fail to meet submission deadlines and lose their nonprofit status. In most other areas of nonprofit operations, external oversight is increasing through the pressure for performance measurement and transparency as well as through the more aggressive pursuit of malfeasance in nonprofits. 
There is also increasing interdependence in funding issues. The fiscal stimulus funds have meant that nonprofits are again focusing on government as a key source of funds, but perhaps the biggest impact of the financial crisis is the increasing tendency towards direct funding and subsidization by the nonprofit sector of government initiatives (as opposed to private donors funding purely nonprofit initiatives). One of the Obama administration's flagship initiatives for nonprofits, the Social Innovation Fund combines Federal government appropriations with some $\$ 50$ million in foundation and other philanthropic contributions to fund projects in nonprofits and government - recipients in the first round of funding announced in July 2010 included the Mayor's Fund for the City of New York and the Barren River District Health Department in Kentucky. In Washington DC, a Schools Chancellor, Michelle Rhee, sought to fund performance pay for public school teachers partly through private foundation grants.

Nonprofits also appear to be re-asserting their right to advocacy, parlaying their greater proximity to government and increased public profile into a more active participation in the policy process. However, it is seen as necessary to provide some explicit protection of the right to advocate in order to avoid the possible "chilling effect" of the fear of losing government funding (even when the nonprofits are using other, nongovernment, funding for advocacy). As the Aspen Institute notes (Aspen Institute 2002: 8), "nonprofit organizations operating in partnership with government must be permitted to pursue their privately supported advocacy activities... [as] active participation in the policy process is a fundamental function of the non- profit sector in a democratic society and one that must be encouraged." From the foundation sector there appears to be a renewed interest in funding advocacy, as attested by the recent publication of "how to" guides (GrantCraft 2005) and calls for the lifting of the existing restrictions (Sherlock and Gravelle 2009).

The increasing interdependence means that there are diminishing domains of truly separate activity for the two sectors. What was once the domain of government is increasingly being outsourced to, or subsidized by, nonprofits and what was once the domain of private nonprofit initiative is increasingly funded and regulated by government.

\section{Conclusion}

An interest in strengthening relationships between governments and nonprofits has (re)surfaced over the past few years in the U.S., as government agencies have more explicitly recognized the contributions that nonprofit organizations make to society and have increased their efforts to promote the sector and to build nonprofit capacity. Industry associations and leadership organizations in the 
Casey: Collaborative Government-Nonprofit Relations in the U.S.

nonprofit sector have been gaining momentum as they build connections, cohesion, and capacity within the sector. With both governments and nonprofits coming to the table with renewed energy and a clearer focus, there appears to be a greater willingness to work collaboratively and to leverage their collective capacity. There have been past attempts at creating closer cooperation, but lack of interest and political will, particularly in economic boom times, as well as the absence of clear institutional pathways appear to have hampered their development and restricted efforts to relatively isolated and smaller scale initiatives.

But now we have the proposal for a Nonprofit Sector and Community Solutions Act and other national initiatives, as well as more locally focused efforts such as the Arizona Nonprofit Agenda and the New York Mayor's Nonprofit Initiative, all of which constitute the new wave of attempts to construct a more cooperative relationship between governments and nonprofits. Are these initiatives harbingers of a new era of sector-to-sector government-nonprofit relations in the U.S. that will supplant the former structures based on programs and industries? Or will the Council on Nonprofit Organizations and Community Solutions proposed in the Act or the Commission on Cross-Sector Partnerships for America's Progress proposed in the Forward Together Declaration go the way of the hapless permanent commission recommended by Filer in the 1970s?

The Act languished in a House Committee and died there at the end of the $111^{\text {th }}$ Congress. The National Council of Nonprofits in its 2011 Public Policy Agenda has continued its call for the enactment of the "critical and essential elements" of the proposed 2010 Act in order to make the federal government a more productive partner with nonprofit organizations (National Council of Nonprofits 2011), and at the time of the writing of this article in early 2011 there are indications that the Act will be reintroduced to face the new Republican majority in the $112^{\text {th }}$ Congress, but there is no firm date. In the meantime, President Obama established in December 2010 a White House Council for Community Solutions to engage prominent business and nonprofits leaders in "cross-sector collaborations", with Michelle Obama as the Honorary Chair. The process of establishing the new Council appropriated much of the language of the 2010 Act and established a stronger symbolic presence for nonprofits within the Obama administration, but "cross-sector" was defined as involving the "nonprofit, philanthropic and private sectors" and the only direct representation of the administration is through the Executive Director of the Council secretariat (White House Council for Community Solutions 2011). Other national initiatives appear to be flagging: the Nonprofit Congress website was discontinued and the annual meeting of the Nonprofit Congress was cancelled in 2009 and substituted with a lobbying day in Washington, because of budgetary considerations and because sector support shifted to lobbying in support of the proposed Act; and there 
appears to have been little activity in support of the Forward Together Declaration since the first months after its launch in 2009.

At the state level, the new Governor of Connecticut moved swiftly to fulfill what had been a campaign promise to appoint a nonprofit liaison to his cabinet, but in other states, candidates and newly elected Governors avoided committing to such positions despite the entreaties of many state nonprofit associations. And there is no firm news yet of the fate of the landmark liaison structures previously created in California and Michigan by Governors who have now left office (and in both cases were replaced by Governors from the opposing party).

These initiatives appear to have a certain bipartisanship - three of the 22 cosponsors of the 2010 proposed Act were Republicans, and Republican Governors and Mayors such as Schwarzenegger and Bloomberg have been early advocates of more collaborative relations - but it remains to be seen how new Republican majorities and the deep financial crises affecting all levels of government in the U.S. impact the relationships between the sectors. However, whatever the future holds for any individual initiative, they are all still strong indicators that momentum continues for new policy agendas that swing the pendulum towards cross-sector partnership and collaborative paradigms. The increased intensity of transactions between the sectors continues to create institutional pressure for processes and structures that can reduce uncertainties.

\section{References}

Alliance of Arizona Nonprofits. (2008). The Arizona Nonprofit Agenda. Retrieved $11 / 5,2008$, from http://www.arizonanonprofits.org/arizonanonprofits/one voice arizona.aspx

Anheier, H. (2005). Nonprofit Organizations: Theory, Management, Policy. New York: Routledge.

Anheier, H., \& Kendall, J. (2001). Third Sector Policy at the Crossroads: An International Nonprofit Analysis. London: Routledge.

Aspen Institute. (2000). The Nonprofit Contribution to Civic Participation and Advocacy. Washington DC: Aspen Institute. Retrieved from http://www.aspeninstitute.org/publications/nonprofit-contribution-civicparticipation-and-advocacy 
Casey: Collaborative Government-Nonprofit Relations in the U.S.

Aspen Institute. (2002). The Nonprofit Sector and Government: Clarifying the Relationship. Washington DC: Aspen Institute;. Retrieved from http://www.aspeninstitute.org/publications/nonprofit-sector-andgovernment-clarifying-relationship

Auger, D. A. (2011). State Level Issues and Challenges Facing the Nonprofit Sector. In ARNOVA (Ed.), Public Policy for Nonprofits: A Report on ARNOVA's Symposium of October 2010 (pp. 77-84). Indianapolis, IN: ARNOVA.

Brown, D., \& Jagadananda. (2007). Civil Society Legitimacy and Accountability: Issues and Challenges. Hauser Center for Nonprofit Organizations, Kennedy School of Government, Working Paper No. 32. Cambridge, MA: Harvard University. Retrieved from http://www.ksghauser.harvard.edu/PDF XLS/workingpapers/workingpap er 32.pdf

Bullain, N., \& Toftisova, R. A. (2005). A Comparative Analysis of European Policies and Practices of NGO-Government Cooperation. The International Journal of Not-for-Profit Law, 7(4), 64-112. Retrieved from http://www.icnl.org/knowledge/ijnl/vol7iss4/art 1.htm

California Association of Nonprofits. (2007). Ensuring Nonprofit Integrity. Capitola CA: California Association of Nonprofits. Retrieved from http://www.canonprofits.org/index.php?option $=$ com docman\&task $=\mathrm{doc} d$ ownload\&gid $=51 \&$ Itemid $=114$

Carter, S., \& Speevak Sladowski, P. (2008). Deliberate Relationships between Government and the Nonprofit/Voluntary Sector: An Unfolding Picture. Ottawa: Wellesley Institute and the Centre for Voluntary Sector Research and Development.

Casey, J., \& Dalton, B. (2006). The Best of Times, the Worst of Times: Community-Sector Advocacy in the Age of 'Compacts'. Australian Journal of Political Science, 41(1), 23.

Casey, J. (2009). The US: Compact Free, but Increasingly Deliberate (working paper for 2009 ARNOVA conference). Unpublished manuscript. Retrieved July 20, 2010, from

http://sites.google.com/site/johncaseypublications/communitysector/Compacts Arnova Nov09 Finalcorrected.doc 
Casey, J., Dalton, B., Melville, R., \& Onyx, J. (2009). International Perspectives on Strengthening Government-Nonprofit Relations: Are Compacts Applicable to the USA? (Working Paper Series ed.). New York: Center for Nonprofit Strategy and Management, Baruch College, City University of New York. Retrieved from http://www.baruch.cuny.edu/spa/researchcenters/nonprofitstrategy/docum ents/Casey Compacts0309.pdf

Casey, J., Dalton, B., Melville, R., \& Onyx, J. (2010). Regulating GovernmentCommunity Sector Relations -- international experiences with Compacts. Voluntary Sector Review, 1(1), 59-76.

Commission on the Compact. (2007). Compact on Relations between the Government and the Voluntary and Community Sector in England. Retrieved December 5, 2007, from http://www.thecompact.org.uk/shared asp files/GFSR.asp?NodeID=1003 $\underline{18}$

Craig, G., Taylor, M., \& Parkes, T. (2004). Protest or Partnership? The Voluntary and Community Sectors in the Policy Process. Social Policy and Administration, 38(3), 221-239.

CVSRD (The Centre for Voluntary Sector Research and Development). (2009). A Gathering of Counterparts. Retrieved 11/1, 2009, from http://www.cvsrd.org/eng/connections-communities/cc counterparts.html

Filer Commission. (1975). Giving in America: Toward a Stronger Voluntary Sector: Report of the Commission on Private Philanthropy and Public Needs. Washington DC: US Department of the Treasury.

Fyfe, N. R. (2005). Making Space for "Neo-Communitarianism"? The Third Sector, State, and Civil Society in the UK. Antipode, 37(3), 536-557.

GrantCraft. (2005). Advocacy Funding: The Philanthropy of Changing Minds. New York: The Ford Foundation. Retrieved from http://www.grantcraft.org/index.cfm?fuseaction=Page.ViewPage\&pageId $\underline{=1309}$ 
Casey: Collaborative Government-Nonprofit Relations in the U.S.

Grønbjerg, K. A., \& Salamon, L. M. (2004). Devolution, Marketization, and the Changing Shape of Government-Nonprofit Relations. Washington DC: Aspen Institute.

Hall, P. D. (2006). A Historical Overview of Philanthropy, Voluntary Associations, and Nonprofit Organizations in the United States, 16002000. In R. Steinberg, \& W. W. Powell (Eds.), The Nonprofit Sector: A Research Handbook (2nd ed., pp. 32-65). New Haven: Yale University Press.

Hudson Institute. (2010). Too Close for Comfort? Obama and the Foundations. Retrieved 7/29, 2010 from http://www.hudson.org/index.cfm?fuseaction=hudson upcoming events\& id $=749$

JHUCCS (Johns Hopkins University Center for Civil Society). (2009). The Forward Together Declaration. Baltimore: Johns Hopkins University Center for Civil Society. Retrieved from http://www.jhu.edu/listeningpost/forward/

Kendall, J. (2003). The Voluntary Sector: Comparative Perspectives in the UK. London: Routledge.

Krauskopf, J. (2001). Recommendations on Human Services Policy for the Next New York City Mayor. New York: Aspen Institute Roundtable on Comprehensive Community Initiatives for Children and Families. Retrieved from http://www.aspeninstitute.org/publications/recommendations-humanservices-policy-next-new-york-city-mayor-and-council

Lewis, J. (2005). New Labour's Approach to the Voluntary Sector: Independence and the Meaning of Partnership. Social Policy and Society, 4(2), 121-131.

McCollum, R. B. (2010). Giving the US Nonprofit Sector a Seat at the Federal Table. Retrieved 7/29, 2010, from http://thehill.com/blogs/congressblog/campaign/109795-giving-the-us-nonprofit-sector-a-seat-at-thefederal-table-rep-betty-mccollum

Najam, A. (2000). The four C's of the Third Sector-Government Relations: Cooperation, Confrontation, Complementarity and Cooptation. Nonprofit Management \& Leadership, 10(4), 375-396. 
National Council of Nonprofits. (2009). Stimulus Grant Tips and Thoughts. Special Reports on the Economic Stimulus and Recovery, \#2. Washington DC: National Council of Nonprofits. Retrieved from http://www.councilofnonprofits.org/content/stimulus-grant-tips-and$\underline{\text { thoughts }}$

National Council of Nonprofits. (2010). History of the National Council and the State Association Network. Retrieved 7/29, 2010, from http://www.councilofnonprofits.org/about-us/history

National Council of Nonprofits. (2011). 2011 Public Policy Agenda. Retrieved 3/26, 2011 from http://www.councilofnonprofits.org/public-policy/2011public-policy-agenda

Nonprofit Congress. (2008). About the Nonprofit Congress. Retrieved December 5, 2007, from http://www.nonprofitcongress.org/?q=about

Osborne, S., \& McLaughlin, K. (2002). Trends and Issues in the Implementation of Local 'Voluntary Sector Compacts' in England. Public Money and Management, 22(1), 55-64.

Paletta, A. (2010, April 10). The Fawning of the Foundations. Wall St Journal, Retrieved from http://online.wsj.com/article/SB1000142405274870447120457521075125 $\underline{4846816 . h t m l}$

Perry, S. (2008, November 13). Think Tanks Propose White House Office of Social Entrepreneurship. The Chronicle of Philanthropy. Retrieved from http://philanthropy.com/blogPost/Think-Tanks-Propose-White/10835/

Rucker, P. (2008, August 19). Some Nonprofits Push for Increased Federal Involvement. Washington Post. Retrieved from http://www.washingtonpost.com/wpdyn/content/article/2008/08/18/AR2008081802407.html

Saidel, J. R. (1991). Resource Interdependence: The Relationship between State Agencies and Nonprofit Organizations. Public Administration Review, 51(6), 543-553. 
Casey: Collaborative Government-Nonprofit Relations in the U.S.

Saidel, J. R. (2011). Proxy-Partnership Governance Continuum: Implications for Nonprofit Managers. In R. C. Menzel, \& H. White L. (Eds.), The State of Public Administration: Issues, Challenges, and Opportunities. New York: M. E. Sharpe.

Salamon, L. M. (2006). Government-Nonprofit Relations from an International Perspective. In E. T. Boris, \& C. E. Steuerle (Eds.), Nonprofits and Government (2nd ed.,). Washington: Urban Institute Press.

Sherlock, M. F., \& Gravelle, J. G. (2009). An Overview of the Nonprofit and Charitable Sector (CRS Report for Congress 7-5700 ed.). Washington DC: Congressional Research Office. Retrieved from www.fas.org/sgp/crs/misc/R40919.pdf

Smith, S. R., \& Grønbjerg, K. A. (2006). Scope and Theory of GovernmentNonprofit Relations. In W. W. Powell, \& R. S. Steinberg (Eds.), The Nonprofit Sector: A Research Handbook (2nd Edition ed., pp. 221-242). New Haven: Yale University Press.

V3 (Voice, Value and Votes). (2008). Home Page. Retrieved November 5, 2008, from http://v3campaign.org

White House Council for Community Solutions. White House Council for Community Solutions. Retrieved 3/26

http://www.serve.gov/council home.asp\#maincontent

Yankey, J. A., \& Willen, C. K. (2010). Collaboration and Strategic Alliances. In D. O. Renz (Ed.), The Jossey-Bass Handbook of Nonprofit Leadership and Management (3rd ed.,) Jossey-Bass.

Young, D. (2006). Complementary, Supplementary, or Adversarial? In E. T. Boris, \& C. E. Steuerle (Eds.), Nonprofits and Government (2nd ed.,). Washington: Urban Institute Press. 